\title{
Acute Oropharyngeal Candidiasis (Atypical Presentation): A Case Report
}

\author{
Saud Saleh Alsaif and Mohammed Gamal Aly* \\ Department of Otorhinolaryngology-Head and Neck, Saudi Arabia
}

Submission: November 26, 2018; Published: December 04, 2018

*Corresponding author: Mohammed Gamal Aly, Department of Otorhinolaryngology-Head and Neck, Saudi Arabia

\section{Introduction}

Fungal infection of the oropharynx is mostly opportunistic infection occurring in immunocompromised patients. In this case study we report for a rare invasive fungal oropharyngitis occurred in immunocompetent patient

\section{Case Presentation}

51 year old Australian female presented to the E.R. in King Fahd Military Medical Complex, Saudi Arabia, with history of sore throat (burning sensation), fever and decrease oral intake for 3 days not improved by oral antibiotic. She gave history of coming back from Pakistan 2 weeks before the presentation. The patient was medically free with no history of any regular medication.

\section{By Examination}

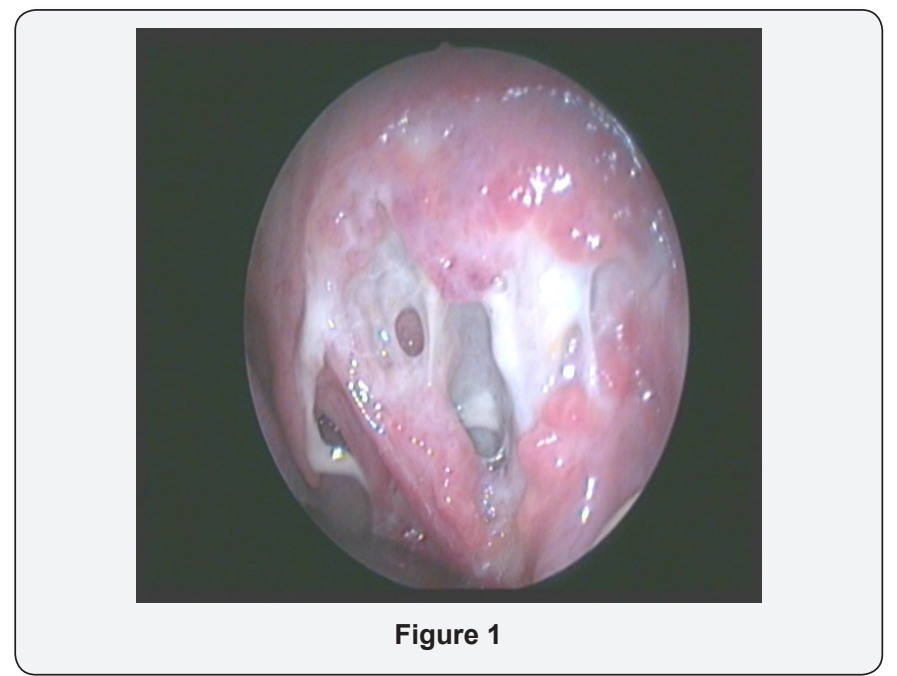

Temperature was 39.6, other vital data was within normal. Throat examination revealed whitish membrane over the soft palate and both tonsils. Neck examination showed bilateral reactionary upper cervical neck lymph nodes and there was minimal trismus. Blood works revealed high WBCs count with slight increase in the percentage of neutrophils. The patient was admitted receiving intravenous broadspectrum antibiotic $2^{\text {nd }}$ generation cephalosporin, metronidazole, and analgesics. Throat swap taken for culture and sensitivity. Two days after the admission soft palate and tonsillar necrosis started although the patient symptoms were improving (Figure 1). Swap result at that time showed streptococcal infection sensitive to the given antibiotics although that the infection and necrosis were getting worse. Deep soft tissue biopsy was taken for histopathological diagnosis. All immunological studies were within normal. Blood viral markers were negative. CT neck with contrast was done. It was unremarkable except for bilateral upper cervical reactionary lymph nodes with no collection.
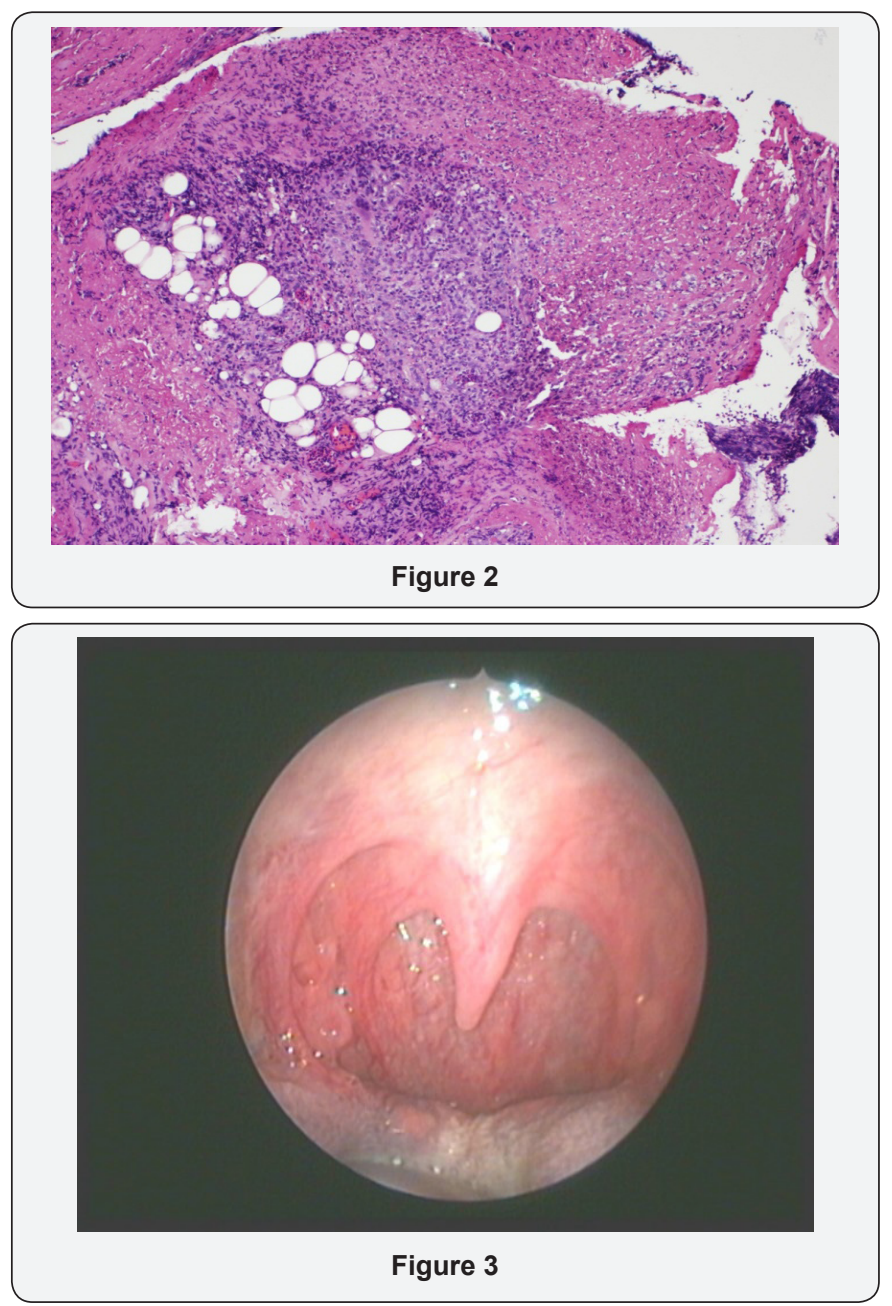
The histopathology results showed acute cellular immunity (active granulomatous reaction), Rather than humoral immunity (Figure 2). Another swap was taken with special concern for TB, fungal infection and diphtheria. Results came after three days showing heavy candida growth and negative for other forms of infection (Figure 3). So the decision was to stop all antibiotics and to start systemic I.V. antifungal according to the culture (fluconazole). Dramatic improvement occurred with the antifungal medication. The progress of the necrosis stopped, and fibrosis started within 5 days. The Patient was discharged home after 7 days of the antifungal medication following up in the clinic with healed soft palate, no signs of infection and no neck lymph nodes (Figure 3).

\section{Discussion}

The patient with acute fungal Candidiasis usually has a history of HIV infection, wears dentures, has diabetes mellitus, or has been exposed to broad-spectrum antibiotics or inhaled steroids [1]. Patients are frequently asymptomatic. However, some of the symptoms may include :Sore throat and painful mouth ulcers, Burning mouth or tongue, Dysphagia, Whitish thick patches on the oral mucosa [2]. Physical examination reveals a diffuse erythema and white patches that appear on the surfaces of the buccal mucosa, throat, tongue, and gums [3].The following are the 5 types of oropharyngeal candidiasis: Membranous Candidiasis, This is one of the most common types and is characterized by creamy-white curd like patches on the mucosal surfaces. Another form is Erythematous Candidiasis, This is associated with an erythematous patch on the hard and soft palates [4]. Fungal pharyngitis can also occur in the form of chronic atrophic candidiasis. This type is also thought to be one of the most common forms of the disease. Angular cheilitis is an inflammatory reaction characterized by soreness, erythema, and fissuring at the corners of the mouth $[4,5]$. In this case study we report for a rare form of fungal infection that can affect the oropharynx where severe and deep tissue invasive infection occurred in immunocompetent patient. The diagnosis of this rare type was confirmed by both histopathology and swab culture. Oropharyngeal Candidiasis( including severe invasive forms) can be treated with either topical antifungal agents (Nystatin, Clotrimazole, amphotericin B oral suspension) or systemic oral azoles (Fluconazole, Itraconazole, or Parconazole)[6].

\section{References}

1. Pappas PG, Rex JH, Sobel JD, Filler SG, Dismukes WE, et al. (2004) Guidelines for treatment of candidiasis. Clin Infect Dis 15 38(2): 161189.

2. De Repentigny L, Lewandowski D, Jolicoeur P (2004) Immunopathogenesis of oropharyngeal candidiasis in human immunodeficiency virus infection. Clin Microbiol Rev 17(4): 729-759.

3. Yang YL (2003) Virulence factors of Candida species. J Microbiol Immunol Infect 36(4): 223-228.

4. Colombo AL, Nucci M, Park BJ, Nouér SA, Arthington Skaggs B, et al. (2006) Epidemiology of candidemia in Brazil: a nationwide sentinel surveillance of candidemia in eleven medical centers. J Clin Microbiol 44(8): 2816-2823.

5. Pappas PG, Kauffman CA, Andes D, Benjamin DK Jr, Calandra TF, et al. (2009) Clinical practice guidelines for the management of candidiasis: 2009 update by the Infectious Diseases Society of America. Clin Infect Dis 48(5): 503-535.

6. Srikumar Chakravarthi, Nagaraja HS (2010) A comprehensive review of the occurrence and management of systemic canididiasis as an opportunistic infection. Microbiology Journal 1 (2): 1-5.

\section{Your next submission with Juniper Publishers} will reach you the below assets

- Quality Editorial service

- Swift Peer Review

- Reprints availability

- E-prints Service

- Manuscript Podcast for convenient understanding

- Global attainment for your research

- Manuscript accessibility in different formats

( Pdf, E-pub, Full Text, Audio)

- Unceasing customer service

Track the below URL for one-step submission https://juniperpublishers.com/online-submission.php 